\title{
Optimization of Silicon solar cell in MATLAB/SIMULINK for improved efficiency
}

\author{
Rutvi Panchal ${ }^{1}$, Lochan Jolly ${ }^{2}$ \\ ${ }^{1}$ M.E. EXTC, Thakur College of Engineering and Technology, Mumbai \\ rutvirpanchal@gmail.com \\ ${ }^{2}$ Professor EXTC, Thakur College of Engineering and Technology, Mumbai \\ Lochan.jolly@thakureducation.org
}

\begin{abstract}
Solar energy is an important part of life and has been in use since the beginning of time. Increasingly, man is learning how to yoke this important resource and use it to replace traditional energy sources. Solar cells are the development to store the solar energy and reproduce electricity. But the amount of energy converted is very less, that is the efficiency of conversion is poor. The main challenge is to improve the efficiency so that the losses can be minimized. The Maximum Power Points are found and the Fill Factor is calculated. The comparative study of silicon solar cell and panels with different sizes is done in this paper using MATLAB and SIMULINK model. The simulated results are compared with practically tested solar cell at Standard Test Conditions (STC).
\end{abstract}

\section{Indexing terms/Keywords}

Solar cell, efficiency, short circuit current, open circuit voltage, MPP, Fill Factor

\section{Academic Discipline And Sub-Disciplines}

Engineering, Electronics and Telecommunication

\section{SUBJECT CLASSIFICATION}

Fiber optics and Device Modeling.

\section{TYPE (METHOD/APPROACH)}

Experiment and Survey

\section{Council for Innovative Research}

Peer Review Research Publishing System

Journal: International Journal of Management \& Information Technology

\author{
Vol. 5, No. 3 \\ editor@cirworld.com \\ www.cirworld.com, member.cirworld.com
}




\section{INTRODUCTION}

The problem of energy crunch has become more and more aggravating, resulting in increased exploitation and research for new power energy resources around the world. In particular, the use of natural energy, especially the solar energy is increasingly emphasized and regarded as an important resource of power energy in the future. By definition, solar energy is that beaming light and heat that is generated from the sun. [1]

\section{The Photoelectric Effect}

A solar cell or photovoltaic cell is a simple PN junction photodiode that can absorb sun's radiation. The photovoltaic effect shown in Fig 1 is the basic physical process through which a PV cell converts sunlight into electricity. Sunlight is composed of photons--packets of solar energy. When photons strike a PV cell, they may be reflected or absorbed, or they may pass right through [2]. The absorbed photons generate electricity. The energy of a photon is transferred to an electron in an atom of the semiconductor device. An array of solar cells converts solar energy into a usable amount of direct current (DC) electricity.

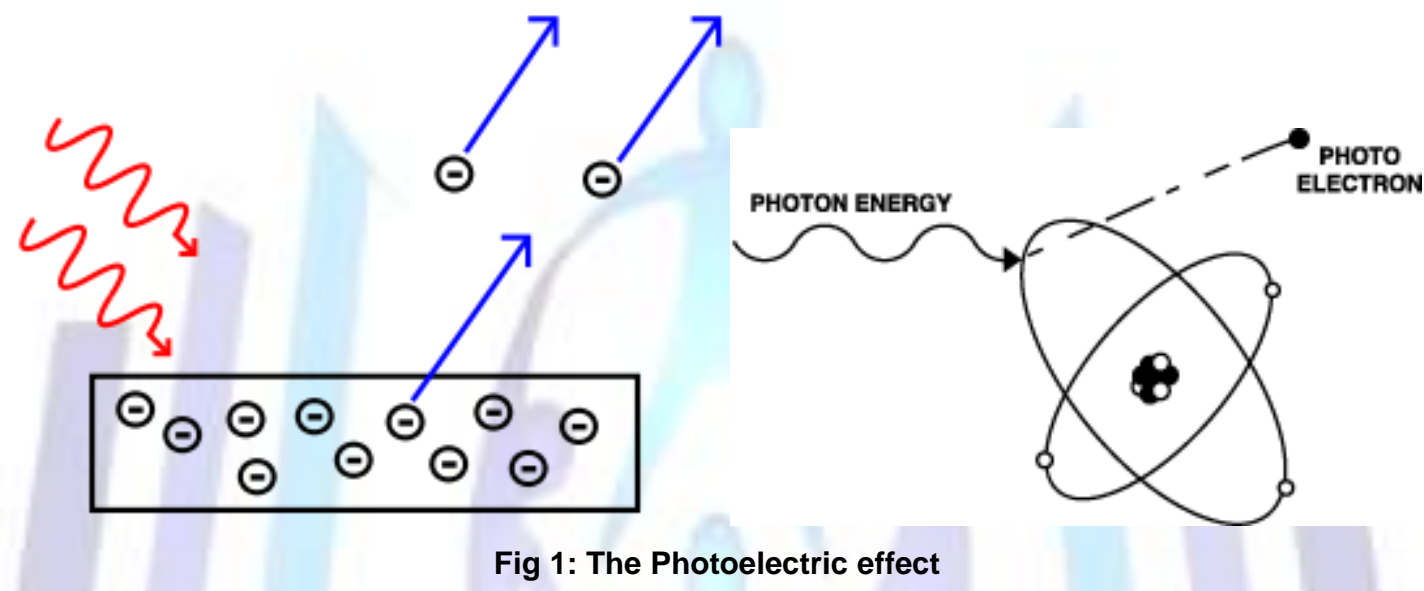

Different material have tendency to absorb different amount of light energy depending upon the band gap of each material. Silicon has band gap of $1.1 \mathrm{eV}$ so it absorbs light energy of minimum $1.1 \mathrm{eV}$ but it gives out energy that is less than $1.1 \mathrm{eV}$. Similarly, Gallium arsenide which has band gap of $1.43 \mathrm{eV}$ absorbs energy more than $1.43 \mathrm{eV}$ but delivers energy less than $1.43 \mathrm{eV}$.

\section{One diode Solar Cell model}

Solar cell is a PN junction diode and can be modeled as a diode with a photo generated current source in parallel [3]. The diode itself has shunt and series resistance as shown in Fig 2.

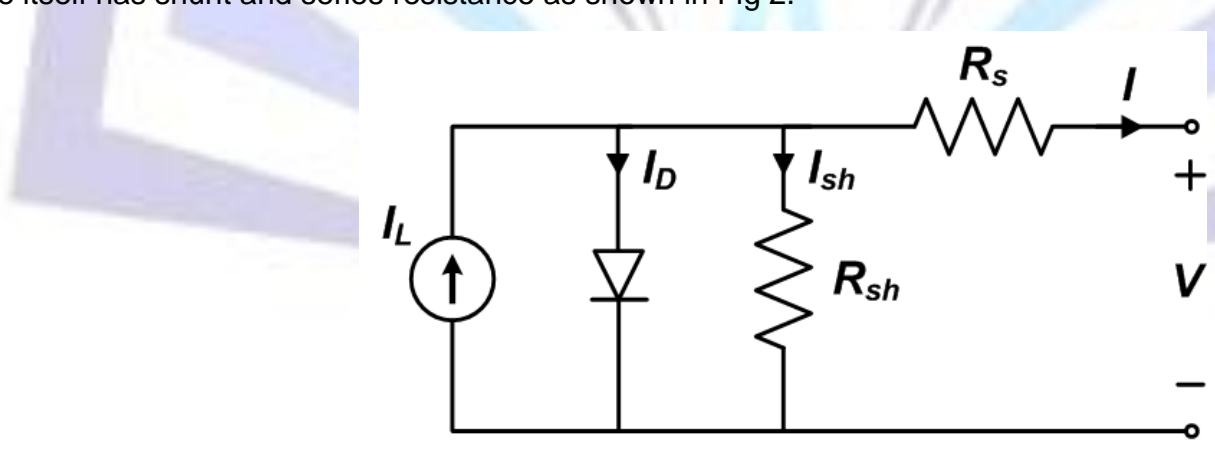

Fig 2: Solar cell electrical equivalent circuit

To understand the electronic behavior of a solar cell, it is useful to create a model which is electrically equivalent. An ideal solar cell may be modeled by a current source in parallel with a diode. In practice no solar cell is ideal, so a shunt resistance and a series resistance component are added to the model.

\section{Solar Parameters}

Irradiance (S): The amount of solar energy reaching the cell is irradiance given in Watts per meter square $\left(\mathrm{W} / \mathrm{m}^{2}\right)$

Open Circuit Voltage $\left(\mathrm{V}_{\mathrm{OC}}\right)$ : It is the maximum voltage available from a solar cell at zero current.

Short Circuit Current $\left(\mathrm{Isc}_{\mathrm{sc}}\right.$ : It is the current through the solar cell when the voltage across the cell is zero. 


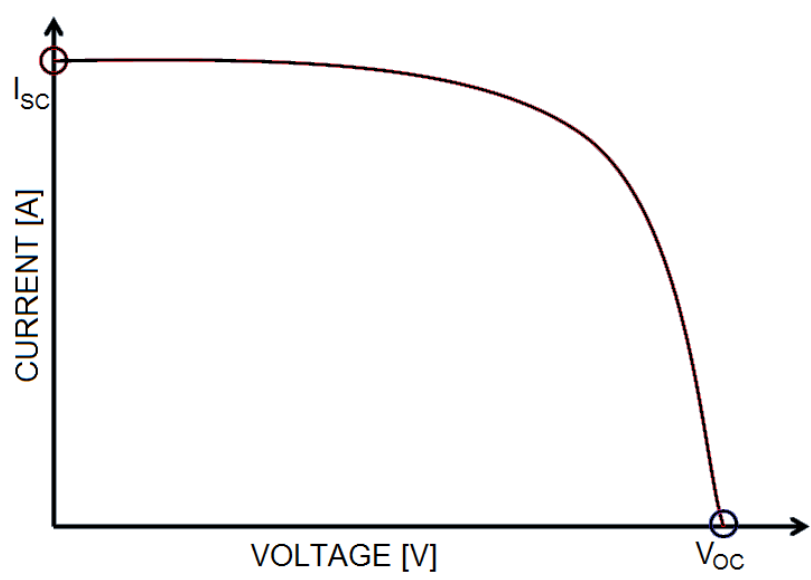

Fig 3: IV curve by joining $I_{s c}$ and $V_{o c}$

The I-V curve of the solar cell follows the same shape as it is in Fig. 3 by making a curve joining Isc and $V_{\text {oc. }}$.

Input Power (Pin): The input to a solar cell is the radiation from sun. Thus the input power to a solar cell depends upon its effective area (Ae) and the radiation (S). The input power is given by AexS.

Output Power (P0): The output power of a solar cell is the given by the product of the output voltage and output current.

Maximum Power Point (MPP): The voltage at which the highest power is observed as shown in Fig 4

Fill Factor (FF): This is the available power at the maximum power point (MPP) divided by the product of open circuit voltage (VOC) and the short circuit current (ISC) Typical commercial solar cells have a fill factor $>0.70$. Cells with high fill factor have less current dissipated as internal loss.

Efficiency $(\eta)$ : The efficiency of a solar cell is determined as the fraction of incident power which is converted to electricity and is defined as: [4]

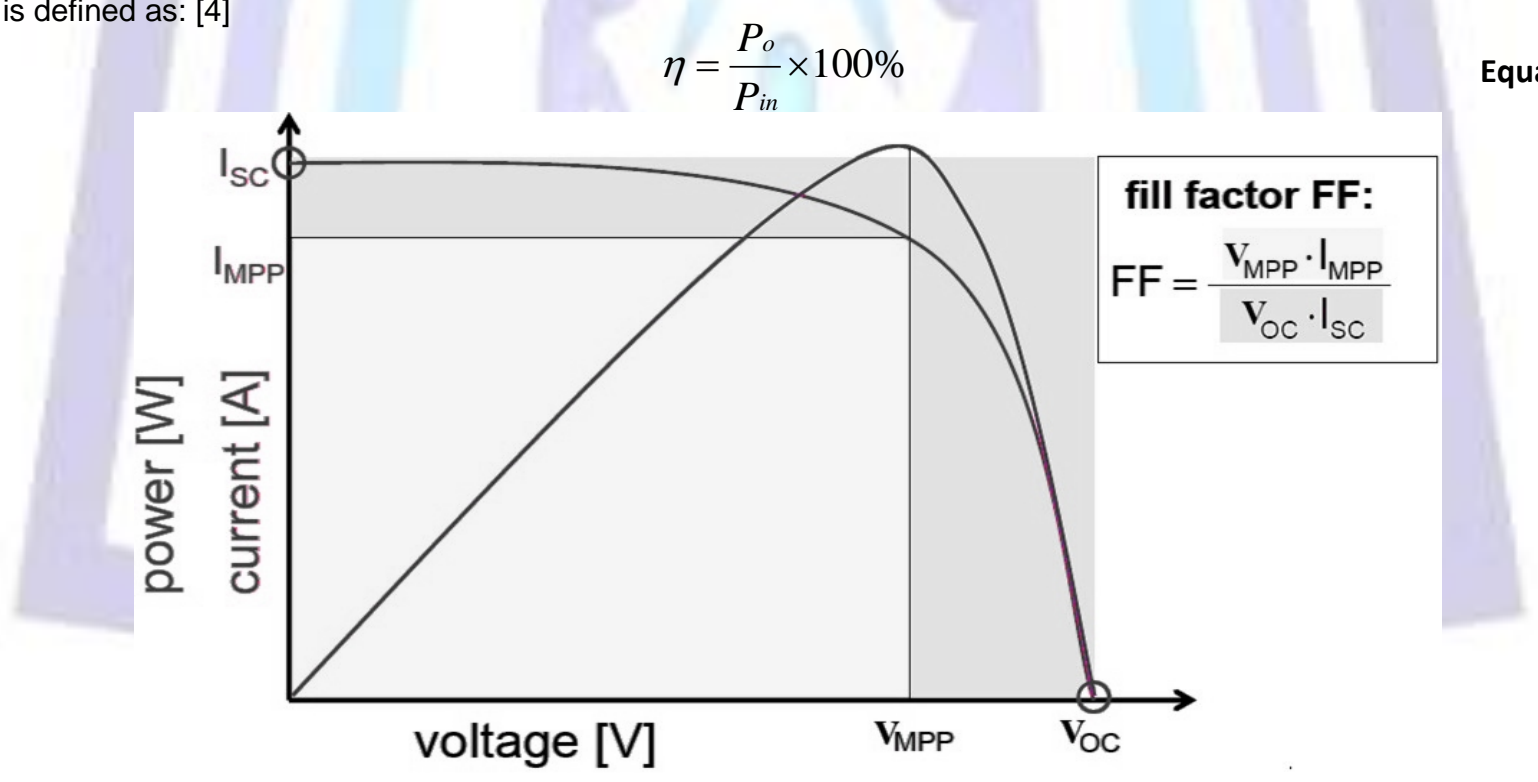

Fig 4: Maximum Power Point ans Fill Factor

\section{Solar Cell Simulation in MATLAB}

As discussed earlier, a solar cell is nothing but a simple PN junction diode along with a photocurrent source, a series and shunt resistor. The entire energy conversion system has been designed in MATLB environment. MATLAB $\AA_{\text {is }}$ a high-level technical computing language and interactive environment for algorithm development, data visualization, data analysis, and numerical computation. [5]

For calculating the total current / Eq. 2 is used

$$
I \stackrel{\dot{I}}{=} I_{p h}-I_{s}\left(\exp \frac{q \mathrm{Vt}}{n k T}-1\right)
$$

Equation 2

In this equation, Iph is the photocurrent, Is is the reverse saturation current of the diode, $\mathrm{q}$ is the electron charge, $\mathrm{Vt}$ is the thermal voltage, $k$ is the Boltzmann's constant, $T$ is the junction temperature, $n$ is the ideality factor of the diode, and Rs 
and Rsh are the series and shunt resistors of the cell, respectively. As a result, the complete physical behaviour of the PV cell is in relation with Iph, Is, Rs and Rsh from one hand and with two environmental parameters as the temperature and the solar radiation from the other hand.

\section{Effects of Solar Radiation Variation}

The most important parameter on which the output of a solar cell depends is the solar radiation which is its only input. The change in radiation varies the output parameters of solar cell [5]. The radiation dependency on solar cell is given by:

$$
I_{p h}=\left[I_{s c}+K_{i}(T-298)\right] \beta
$$

Equation 3

Where, $K i$ is the cell's short circuit current temperature coefficient $\left(\mathrm{A} /{ }^{\circ} \mathrm{C}\right), \beta$ is the solar radiation $\left(\mathrm{W} / \mathrm{m}^{2}\right)$ and $I_{p h}$ is the photocurrent.

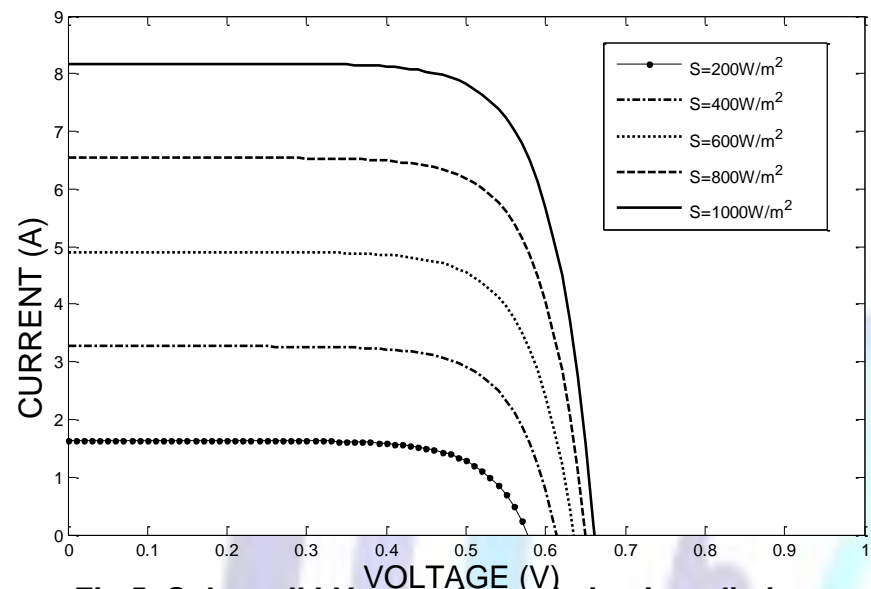

Fig 5: Solar cell I-V curve for variation in radiation

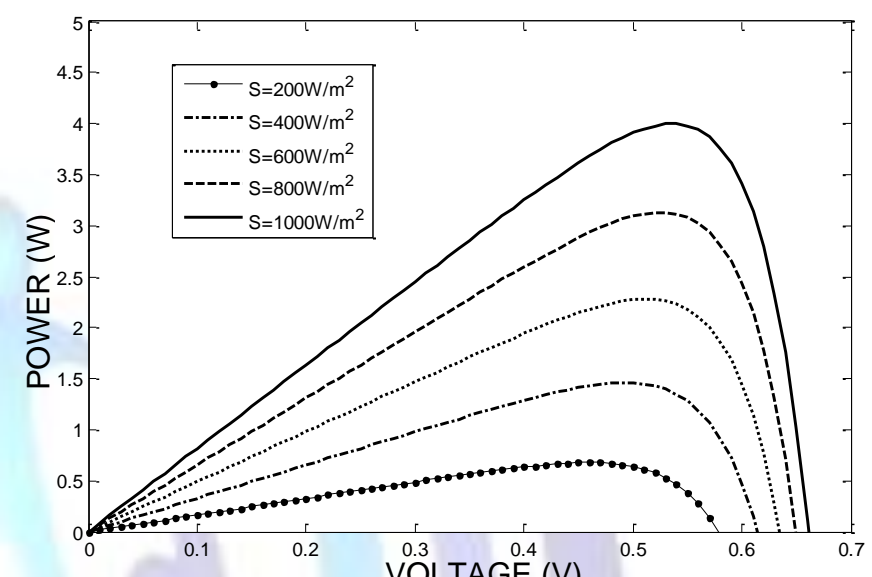

Fig 6: Solar cell P-V curve for variation in radiation

The output results for variation in solar radiation is given in Fig 5 for voltage versus current where it is observed that for the increase in radiation, the current of the solar cell is also increasing. With respect to the Eq 3 , it is clear that the current is directly proportional to the radiation. The characteristic I-V curve tells that there are two regions in the curve: one is the current source region and another is the voltage source region. In the voltage source region (in the right side of the curve), the internal impedance is low and in the current source region (in the left side of the curve), the impedance is high. Irradiance temperature plays an important role in predicting the I-V characteristic, and effects of both factors have to be considered while designing the PV system. Whereas the irradiance affects the output, temperature mainly affects the terminal voltage. Fig 6 which shows voltage versus power curve is used to find the maximum power point that is the voltage at which the maximum power observed. From the I-V, it is observed that the short circuit current increases with increase in irradiance at a fixed temperature. Moreover, from the I-V and P-V curves at a fixed irradiance, it is observed that the open circuit voltage decreases with increase in temperature. In Fig 7 the current versus power curve is plot.

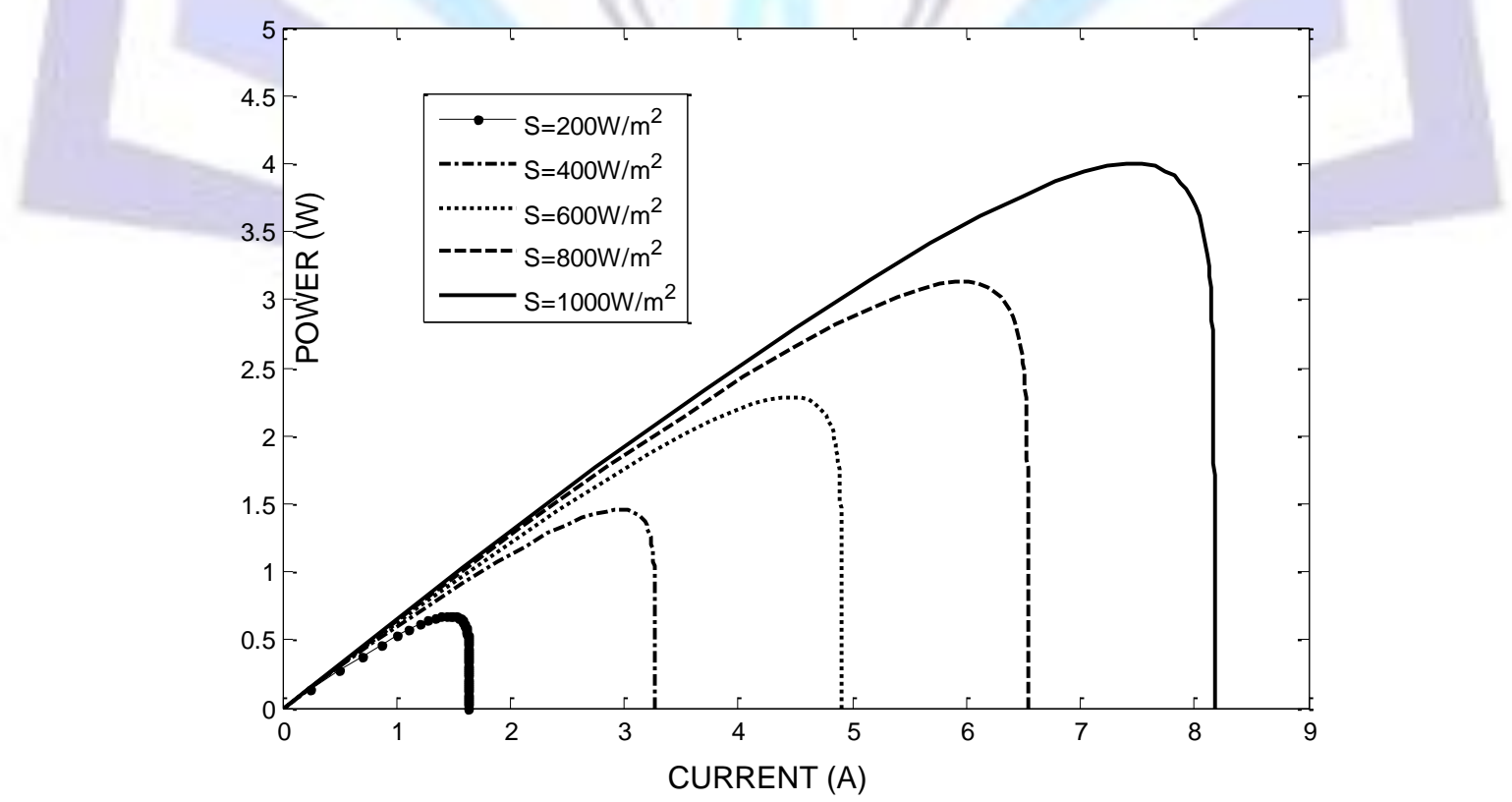

Fig 7: Solar Cell P-I curve for variation in radiation 


\section{Effects of Temperature Variation}

The solar radiation is the only input for the solar cell, but the other indirect input that changes the output characteristics of the solar cell is the temperature. Eq. 3 shows the relation between the temperature and the photocurrent [5]. The change in photocurrent changes the output voltage and current. The Fig. 8, Fig. 9 and Fig 10 give the I-V, P-V and P-I characteristics for various temperatures at a fixed irradiance at $1000 \mathrm{~W} / \mathrm{m}^{2}$.

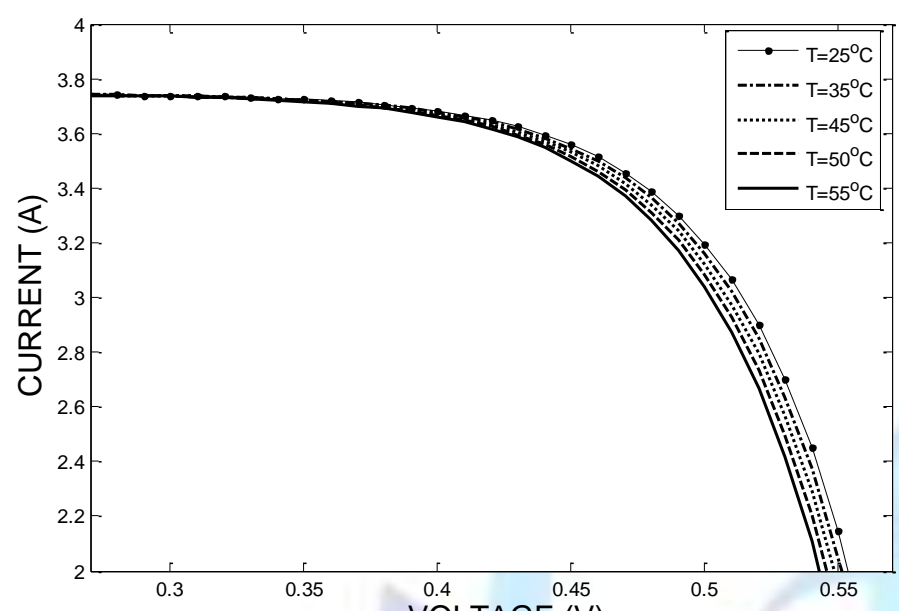

Fig 8: Solar cell I-V cuLTAGE for variation in temperature

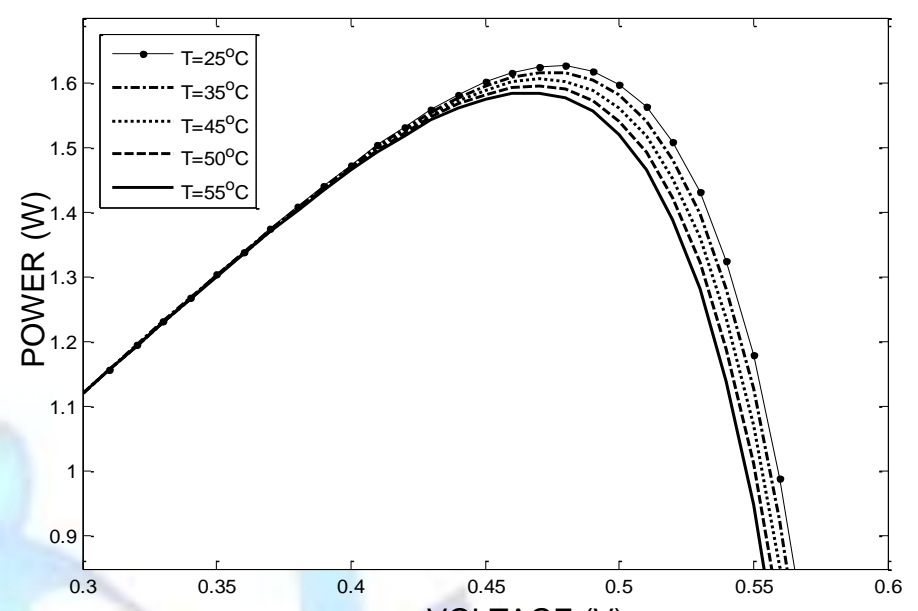

Fig 9: Solar cell P-t curve for variation in temperature

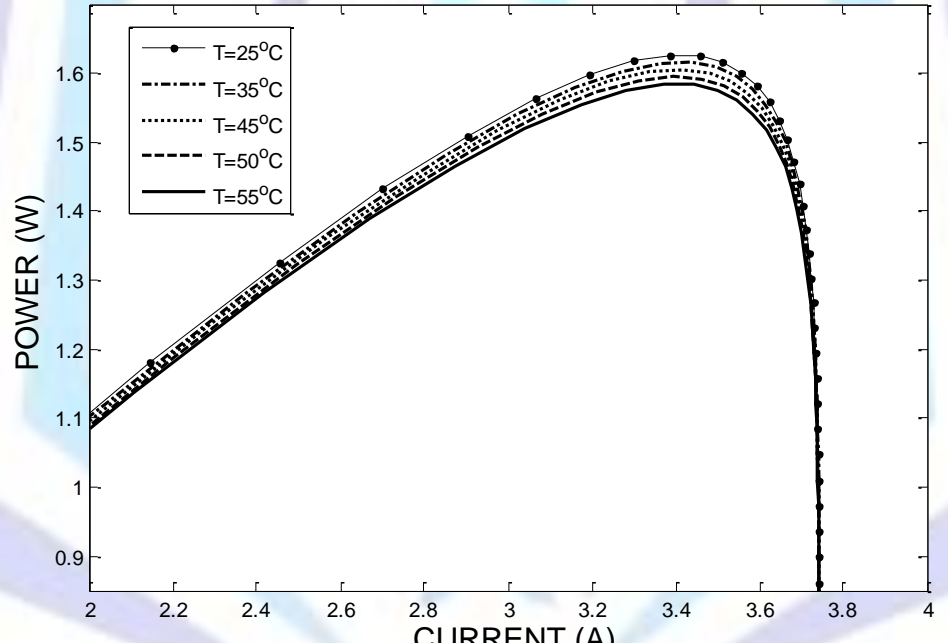

Fig 10: Solar cell $P$-I curve for variation in temperature

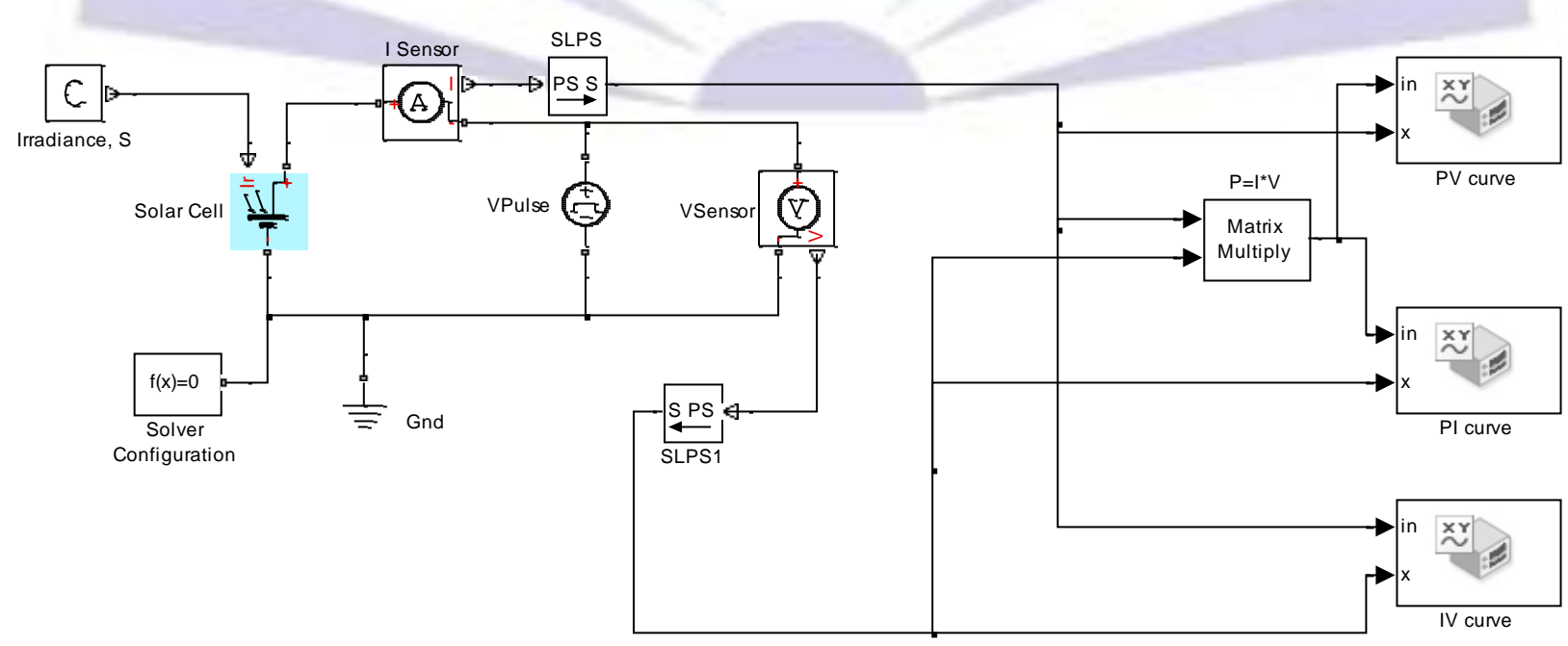

Fig 11: SIMULINK model 


\section{PV Cell Model in SIMULINK}

The MATLAB/SIMULINK [6] model of a Solar cell to measure the output voltage, current, power is shown in Fig 11. This model uses the main block "Solar Cell" in which the values are predefined. For VOC the default value is $0.6 \mathrm{~V}$. The $I_{\mathrm{SC}}$ is set to 7.34A. The values can be changed once a model is created and place the block in it. The terminals of the block are Incident irradiance (Ir), Positive electrical voltage (+) and Negative electrical voltage (-). The Ir terminal is connected to the Irradiance block (C) where a constant value of radiance from sun in $\mathrm{W} / \mathrm{m}^{2}$ can be set. The current sensor and voltage sensors are used to measure current and voltage respectively. Further, to plot the curve of voltage versus current $X Y$ plotter block is used. The plots of output characteristics can be seen in below figures which are tested at STC. The STC has $\mathrm{S}=1000 \mathrm{~W} / \mathrm{m}^{2}, \mathrm{~T}=25^{\circ} \mathrm{C}$ and Air Mass $(\mathrm{AM})=1.5$.

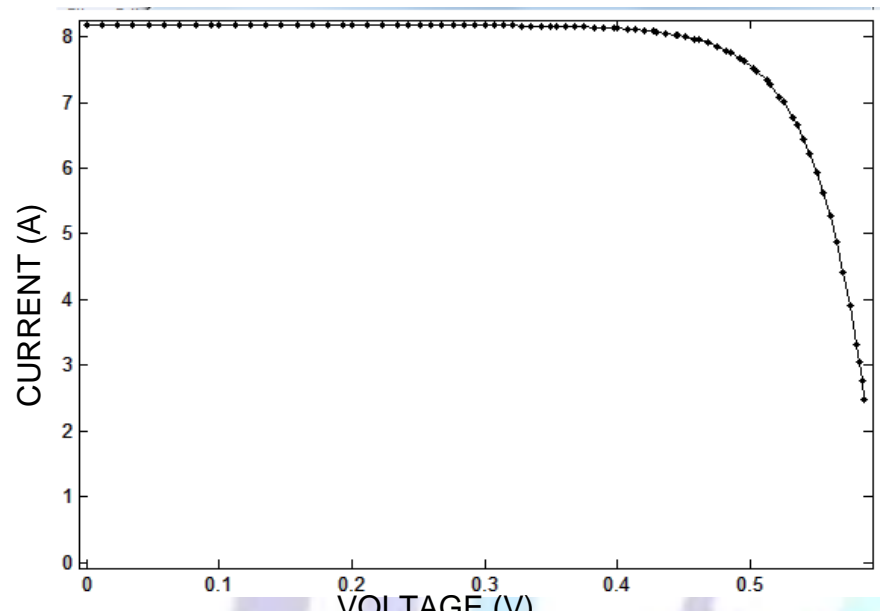

Fig 12: Solar =VAGE

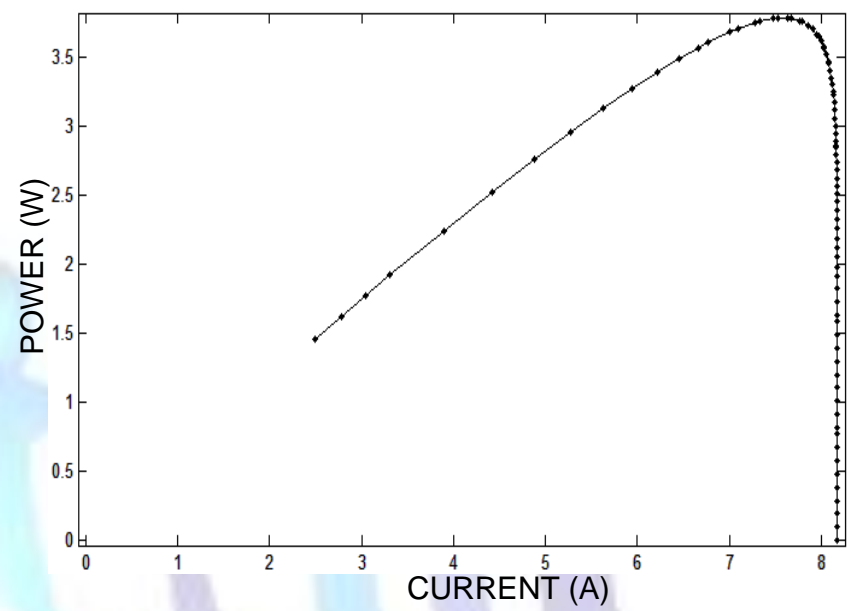

Fig 13: Solar P-I curve in SIMULINK

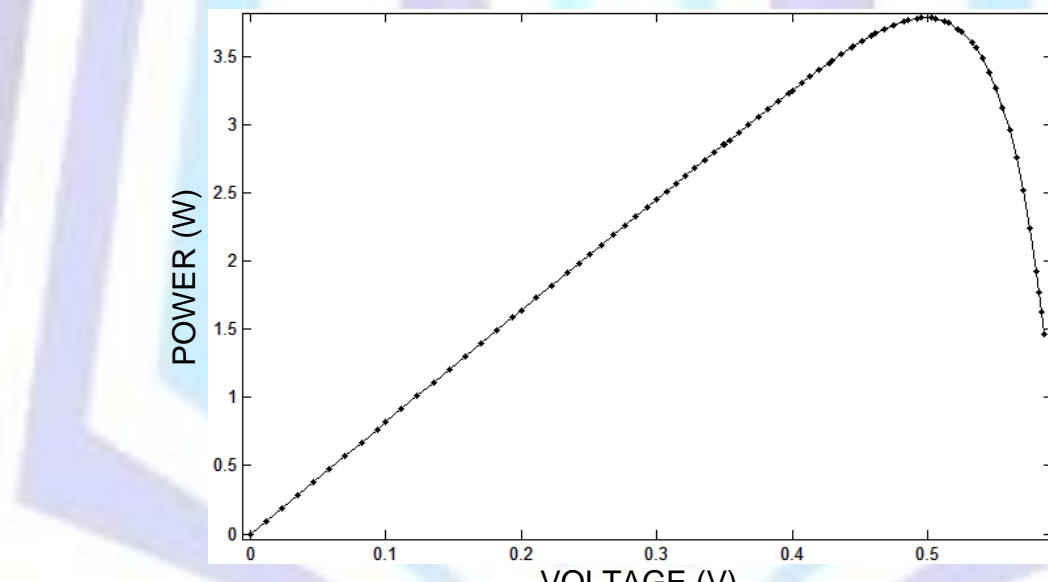

Fig 14: Solar P-VTAGE (V) In SIMULINK

\section{Solar Cell Experimental Setup}

For practically simulating a solar cell QuickSun solar cell simulator [7] which is versatile for quality control and development applications. It evaluates the standard IV-characteristics during a single flash.

The simulator operates on STC. The solar cell is placed on a given space and is exposed to the flash of $1000 \mathrm{~W} / \mathrm{m}^{2}$. The temperature inside the simulator is $25^{\circ} \mathrm{C}$.

The simulator is interfaced with a computer where the output is seen. The output consists of Open Circuit Voltage ( $\left.V_{O C}\right)$, Short Circuit Current $\left(\mathrm{I}_{\mathrm{SC}}\right)$, current at maximum point $\left(\mathrm{I}_{\mathrm{MPP}}\right)$, Voltage at maximum point $\left(\mathrm{V}_{\mathrm{MPP}}\right)$, Fill Factor (FF) and efficiency $(\eta)$.

Fig. 15 shows the practical setup using a QuickSun Solar Simulator. Fig. 16 shows the output which is observed from the Simulator.

The IV curve and PV curve are plotted on same graph so that the simulator software can also calculate the FF and MPP. The additional information other than the curve parameters are the area of cell, no of cells in series and parallel, ambient temperature, corrected temperature, slopes at $V_{\text {Oc }}$ and $I_{\text {sc. }}$. 


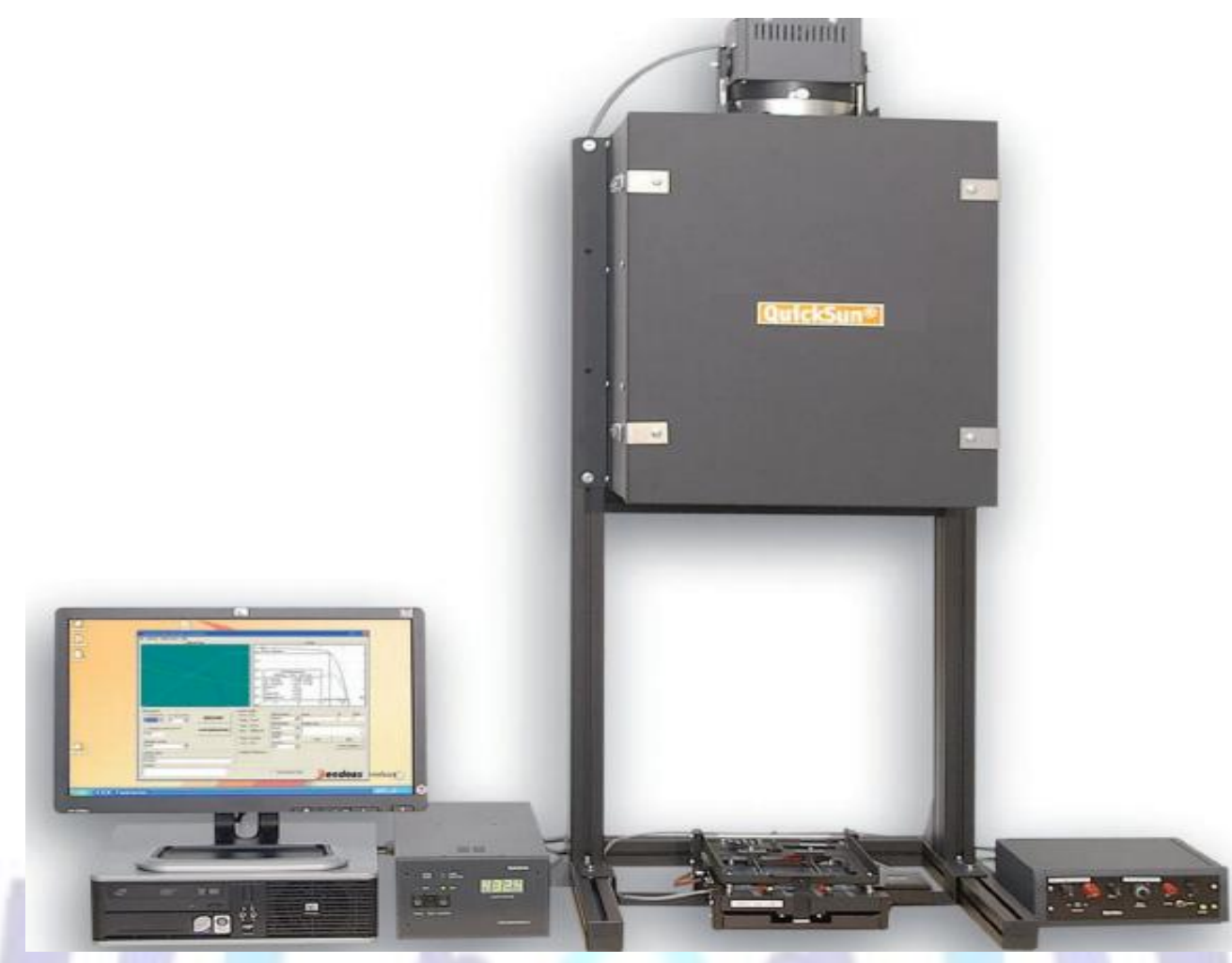

Fig 15: QuickSun Solar Simulator interfaced with computer

The Solar cell which is used is a polycrystalline silicon cell with area of $156 \mathrm{~mm} \times 156 \mathrm{~mm}$.

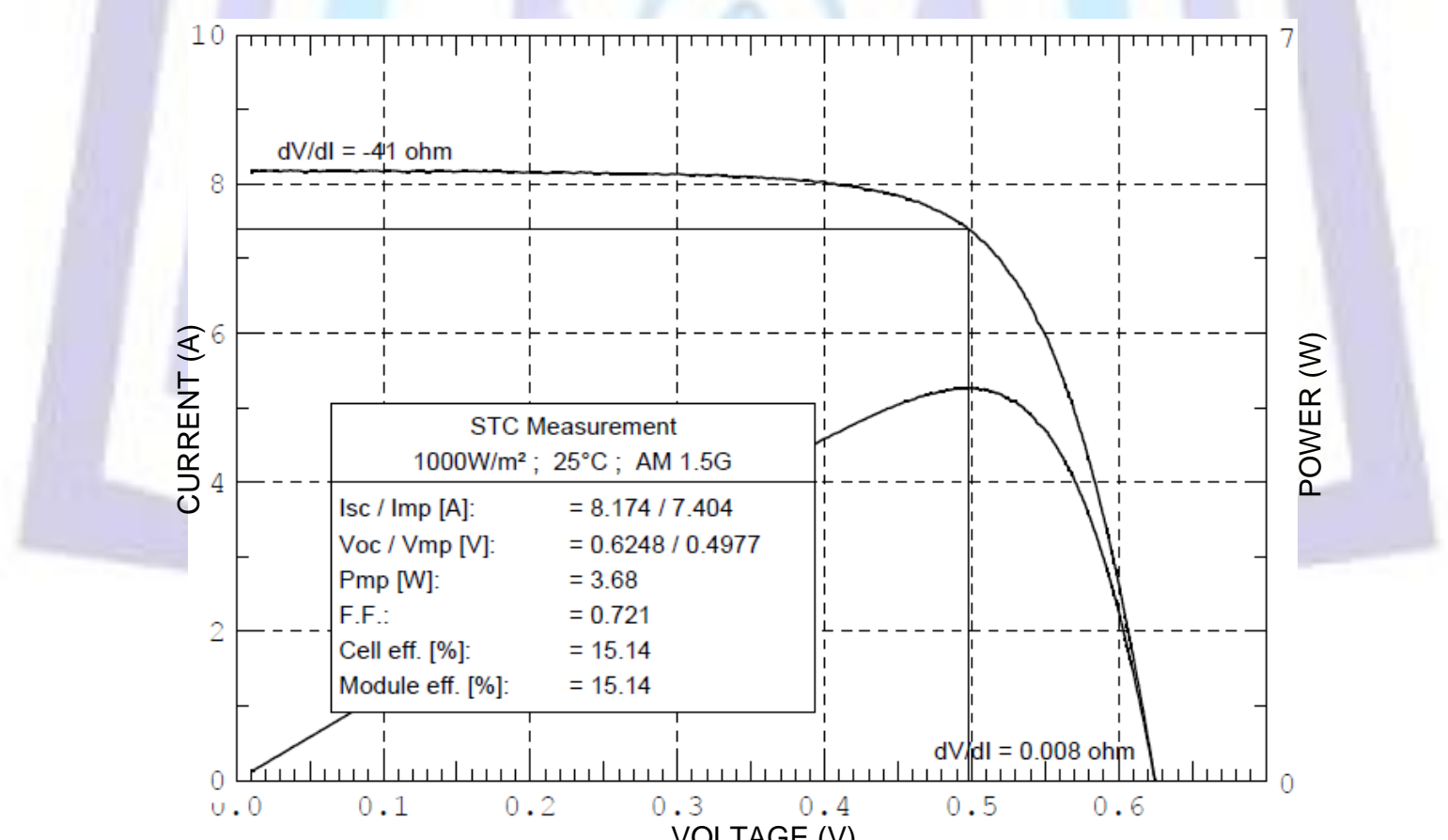

Fig 16: Practicaloutput from simulator

\section{Efficiency of Solar Cell}

The efficiency of solar cell is given in eq. 1. The output power and input power are calculated. Since power is directly proportional to radiance, the efficiency will increase as the radiance increases.

Fig. 17 shows the curve of efficiency versus the radiance.

The efficiency at STC of the solar cell is found out to be $14.185 \%$ 


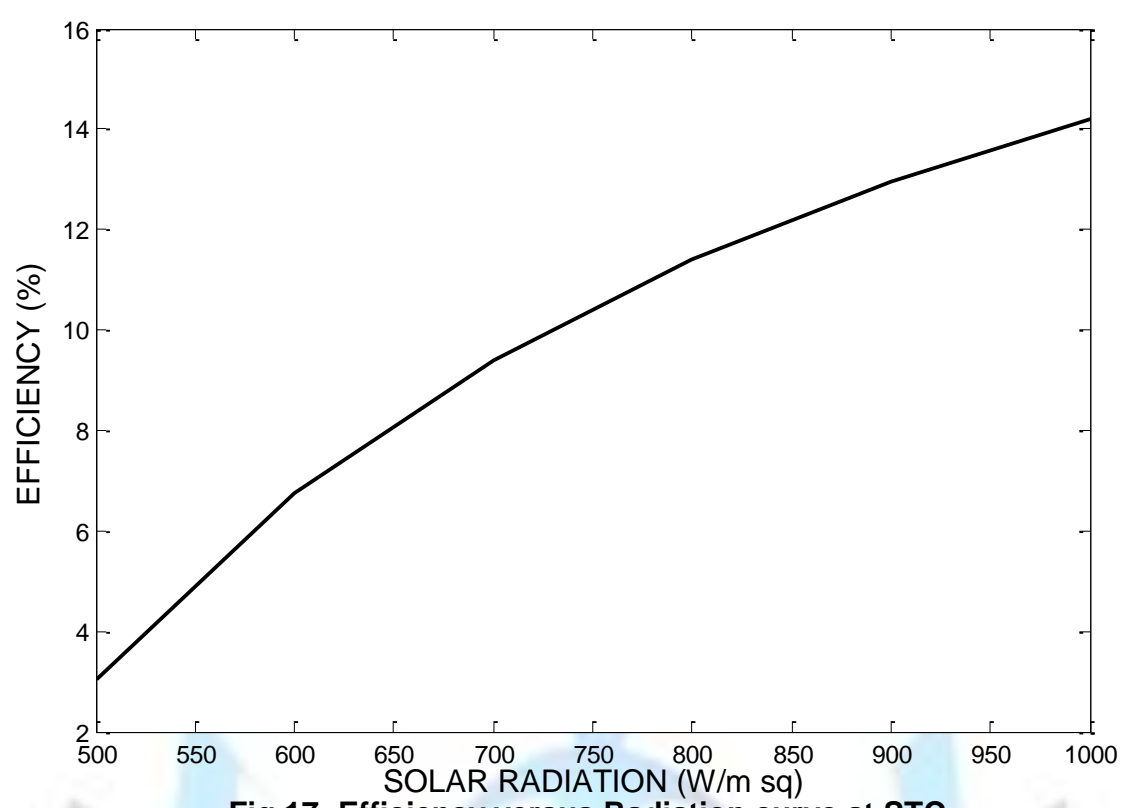

\section{Results and Conclusion}

\section{Maximum Power Point and Fill Factor}

Table 1: Fill Factor

\begin{tabular}{|c|c|c|c|c|c|c|c|}
\hline $\mathbf{S}\left(\mathbf{W} / \mathbf{m}^{2}\right)$ & Vmax (V) & Imax (A) & Voc $(\mathbf{V})$ & Isc $(\mathbf{A})$ & $\begin{array}{c}\text { Vmax } \times \text { Imax } \\
(\mathbf{W})\end{array}$ & $\begin{array}{c}\text { Voc } \times \text { Isc } \\
(\mathbf{W})\end{array}$ & Fill Factor \\
\hline 1000 & 0.53 & 7.5370 & 0.661 & 8.174 & 3.995 & 5.403 & 0.74 \\
\hline 800 & 0.53 & 5.9020 & 0.650 & 6.539 & 3.128 & 4.248 & 0.74 \\
\hline 600 & 0.51 & 4.4730 & 0.635 & 4.904 & 2.281 & 3.112 & 0.73 \\
\hline 400 & 0.49 & 3.0610 & 0.614 & 3.270 & 1.500 & 2.007 & 0.75 \\
\hline 200 & 0.45 & 1.5010 & 0.578 & 1.635 & 0.675 & 0.945 & 0.71 \\
\hline
\end{tabular}

For a solar cell, the more the Fill Factor, the more is the reliability. So it is one of the important factors after efficiency. For a good solar cell, the efficiency has to be greater than $70 \%$. Table 1 shows the calculation of fill factor at different radiations. From this it is observed that the fill factor is constant for different radiation.

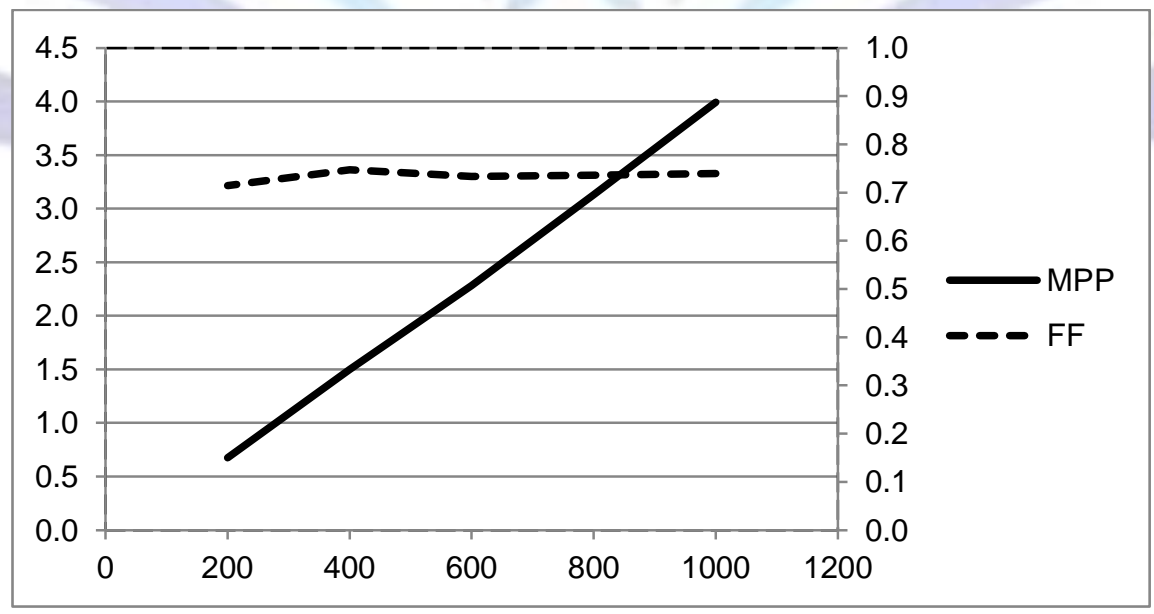

Fig 18: Plot for MPP and FF versus Radiation

The graph in fig 18 which is plotted from the data in table 1 shows that the MPP increases linearly and the FF remains constant for the variation in sun's radiation.

The simulated fill factor is nearly same as the datasheet fill factor. 
Table 2: Comparison of Fill factors of different methods

\begin{tabular}{|c|c|c|}
\hline $\begin{array}{c}\text { Average Fill Factor in } \\
\text { MATLAB }\end{array}$ & $\begin{array}{c}\text { Fill Factor by } \\
\text { SIMULINK }\end{array}$ & $\begin{array}{c}\text { Fill Factor by Quicksun Solar } \\
\text { Simulator }\end{array}$ \\
\hline 0.73 & 0.74 & 0.721 \\
\hline
\end{tabular}

By the formula of fill factor, the FF for different methods is compared and is found to be nearly the same.

\section{Efficiency}

Efficiency being the main parameter of solar cell, it is necessary to try to have maximum efficiency for maximum energy conversion. Table 3 gives comparison of efficiency by all three methods and are nearly same.

Table 3: Comparison of Efficiency

\begin{tabular}{|c|c|c|c|}
\hline & MATLAB & SIMULINK & $\begin{array}{c}\text { Quicksun Solar } \\
\text { Simulator }\end{array}$ \\
\hline Output power & $3.452 \mathrm{~W}$ & $3.6 \mathrm{~W}$ & $3.68 \mathrm{~W}$ \\
\hline Input Power & $24.336 \mathrm{~W}$ & $24.336 \mathrm{~W}$ & $24.336 \mathrm{~W}$ \\
\hline Efficiency & $14.185 \%$ & $14.8 \%$ & $15.1 \%$ \\
\hline
\end{tabular}

The open circuit P-V, P-I, I-V curves were obtained from the simulation of the PV cell designed in MATLAB environment explains in detail its dependence on the irradiation levels and temperatures. The entire energy conversion system has been designed in MATLB-SIMULINK environment. The various values of the voltage and current obtained have been plotted in the open circuit I-V curves of the PV cell at insolation levels ranging from $200 \mathrm{~W} / \mathrm{m}^{2}$ to $1000 \mathrm{~W} /{ }^{2}$. However the performance of the photovoltaic device depends on the spectral distribution of the solar radiation. The values for all the output parameters are found to be satisfactorily comparable.

\section{ACKNOWLEDGMENTS}

I would like to take the opportunity to express my sincere thanks to my guide Dr. Lochan Jolly for her invaluable support and guidance throughout the work. I would like to thank my M.E. coordinator, Prof. Vinitkumar J. Dongre and the Principal of Thakur college of engineering and Technology, Dr. B. K. Mishra for giving me an opportunity to carry out the research work in my field of interest and encouraging me to publish this paper.

\section{REFERENCES}

[1] Jeyraj Selvaraj, Nasrudin A. Rahim, "Multilevel Inverter For Grid-Connected PV System Employing Digital PI Controller", IEEE Transactions On Industrial Electronics, vol. 56, No. 1, pp. 149-158, 2009.

[2] E. Rudberg, The energy distribution of electrons in the photoelectric effect, Phys. Rev. 48 (1935), 811.

[3] Huan-Liang Tsai, Ci-Siang Tu, Yi-Jie Su, "Development of Generalized Photovoltaic Model Using MATLAB/SIMULINK", Proceedings of the World Congress on Engineering and Computer Science WCECS, San Francisco, USA, 2008.

[4] K. A. EMERY and C. R. OSTERWALD, 1985, SOLAR CELL EFFICIENCY MEASUREMENTS, Solar Energy Research Institute, 1617 Cole Blvd., Golden, CO 80401 (U.S.A.)

[5] Tarak Salmi, Mounir Bouzguenda, Adel Gastli, Ahmed Masmoudi, 2012, MATLAB/Simulink Based Modeling of Solar Photovoltaic Cell, International Journal of Renewable Energy Research.

[6] INTRODUCTION TO MATLAB® \& SIMULINK A Project Approach Third Edition.

[7] Ruukinkuja 1 FIN-02330 Espoo endeas, 2009, quicksun Solar Simulator.

\section{Author' biography}

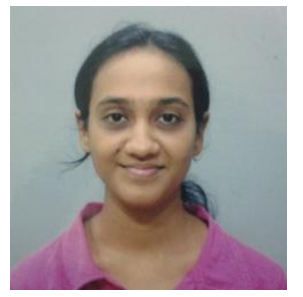

Ms Rutvi R. Panchal is a M.E. second year student and past faculty of Thakur College of Engineering and technology, Mumbai University. Her area of Specialisation is Fiber Optics and Device Modeling. She has published one paper in international confrerence. 
Dr. Lochan Jolly is working as a Professor in Thakur College of Engineering, Mumbai University. Her area of Specialisation is Microelectronics. she has guided over 12 UG level projects and $6 \mathrm{PG}$ level projects. She has published 6 papers in national conference, 10 papers in international conference and 15 papers in an international journal. 